\title{
Imitação e emulação entre o discurso histórico e a arte pictórica na representação da prática dos sacrifícios no templo de Viztziliputztli
}

\author{
Imitation and emulation between rhetoric \\ discourse and pictorial art in the representation \\ of sacrifices practice in Viztzilipuztli temple
}

Deolinda de Jesus Freire*

\section{RESUMO}

A escrita da História no século XVII, na Península Ibérica, tem como base o esquema bíblico cristão, logo, a verdade dos fatos dificilmente pode ser comprovada. Essa é uma das razões de a narração histórica se apoiar na repetição dos lugares-comuns da memória cristã para que os eventos narrados sejam considerados verdadeiros porque repetidos de acordo com o propósito divino. As edições ornadas com gravuras estabelecem uma tensão entre a verdade que se narra e o que se vê pintado, instituindo uma competição entre o discurso histórico e a arte pictórica. As gravuras imitam os lugares-comuns empenhados pelo cronista, amplificando-os para superar o discurso histórico e, assim, persuadir e comover o leitor e espectador a partir dos afetos com a visão de uma imagem que apenas se formava a partir da leitura e da memória cristã. $O$ presente trabalho propõe uma leitura da competição entre o discurso histórico e a arte pictórica na edição ornada com gravuras da Historia de la conquista de México de Dom Antonio de Solís, publicada em Bruxelas no ano de 1704, em língua castelhana. A partir de duas imagens do Livro III - o templo de Viztzilipuztli e a prática do sacrifício -, analisamos como se estabelece o procedimento retórico de imitação e emulação entre o discurso e a gravura e como as artes - História e Gravura - competem entre si.

Palavras-chave: Discurso histórico; Gravuras; Imitação e emulação.

* Universidade Federal do Triângulo Mineiro (UFTM). 
Freire, D. J.

Imitação e

emulação entre o discurso histórico e a arte pictórica na representação da prática

dos sacrifícios no templo de Viztziliputztli
Revista Letras, Curitiba, UFPR, n. 97, pp. 106-129, jan./jun. 2018. ISSN 2236-0999 (versão eletrônica)
ABSTRACT

The writing of History in the $17^{\text {th }}$ century, in the Iberian Peninsula, has as its basis the Christian biblical scheme, hence, the truth of facts can hardly be proven. This is one of the reasons why the historical narration relies on the repetition of commonplaces of the Christian memory, so that the narrated events are considered true because they are repeated according to the divine purpose. The editions adorned with engravings establish a tension between the truth that is told and what the readers see painted, instituting a competition between historical discourse and pictorial art. The engravings imitate the commonplaces committed by the chronicler, amplifying them to overcome the historical discourse and, therefore, persuade and move the reader and spectator from the affects with the vision of an image that was only formed from reading and Christian memory. This work offers a reading of the competition between the historical discourse and the pictorial art in the adorned edition with engravings of Historia de la conquista de Mexico by Dom Antonio de Solís, published in Brussels in 1704 in Castilian language. From two images of Book III - Viztzilipuztli's temple and the sacrifice practice -, we analyze how the rhetorical procedure of imitation and emulation between discourse and engraving is established and how the arts - History and Engraving - compete with each other.

Keywords: Historical discourse; Engravings; Imitation and emulation. 
primeira edição em língua castelhana da Historia de la conquista de México
de Dom Antonio de Solís foi publicada em Madri no ano de 1684. Ao
longo de cinco livros, a obra narra a conquista dos povos da Nova Espanha, com destaque para a queda de Tenochtitlan. Após a publicação, a Historia de Solís, cronista $^{1}$ oficial de Carlos II, último rei da Casa de Habsburgo, foi traduzida para outras línguas, como o toscano, o inglês e o francês, tendo tido algumas de suas edições ornadas com gravuras. Dessas edições, selecionamos duas imagens do Livro III da edição publicada em Bruxelas² no ano de 1704, em língua castelhana, para analisar como se estabelece o procedimento retórico de imitação e emulação entre as artes historiográfica e pictórica. O conjunto de gravuras do Livro III, composto por um total de sete imagens, evidencia a chegada do exército castelhano ao lago

1 Referimo-nos a Dom Antonio de Solís como cronista e também historiador, assim, utilizamo-nos das mesmas formas pelas quais é tratado nos discursos da parte introdutória da edição princeps da Historia de la conquista de México. Cronista refere-se à sua função na Corte de Carlos II, e historiador à arte à qual se dedica já na idade madura.

2 A região dos Países Baixos se destacou na arte das gravuras, bem como da pintura, durante os séculos XVI e XVII. 
Freire, D. J.

Imitação e

emulação entre o discurso histórico e a arte pictórica na representação da prática

dos sacrifícios no templo de Viztziliputztli

Texcoco, consequentemente à Tenochtitlan;o encontro entre o soberano asteca Moctezuma e o capitão castelhano Hernán Cortés; e os sacrifícios no templo de Viztzilipuztli. As gravuras do templo e da prática dos sacrifícios compõem o corpus de nossa leitura nesse artigo. ${ }^{3}$

A gravura, como arte, aproxima-se da pintura, pois, além de imitar o pincel, compartilha com ela algumas das etapas de composição. ${ }^{4}$ Abraham Bosse (1801, p. 67), em seu Tratado da Gravura, afirma que podemos considerar a gravura como um modo de pintar, ou desenhar, com traços, sendo que o método mais natural para essa arte é imitar "o toque do pincel, se for hum quadro o que se copia : Ora naõ ha certamente hum quadro feito com arte onde se não descubra o manejo do pincel". ${ }^{5}$ Uma das diferenças entre a gravura e a pintura refere-se à técnica empregada, pois a finalização da primeira se dá a partir de um suporte metálico. Após o processo, o desenho fica gravado em uma fôrma, podendo ser reproduzido inúmeras vezes sem os créditos do artífice ou do gravador da edição original. Quando reproduzidas, o leitor - e espectador -, em alguns casos, perde a referência da autoria como também a datação das gravuras. ${ }^{6}$

A imitação e a emulação entre o discurso historiográfico e a arte pictórica permitem-nos estabelecer a competição ${ }^{7}$ entre a arte da História e da Gravura uma vez que as edições ornadas com imagens eram consideradasespaço de competição discursiva e artística para o século XVII. Nas edições enriquecidas com gravuras, o texto do cronista praticamente não se altera, mas as imagens ganham detalhes e riquezas de modo a rivalizarem diretamente com o texto escrito. Com essa abordagem, evitamos o anacronismo em ler as imagens como ilustrações do texto, prática mais usual atualmente, instituída por uma crítica especializada que despreza os preceitos retóricos e pictóricos dos gêneros da época colonial. Como nos lembra Sinkevisque (2005, p. 367), ainda que as imagens circulem impressas aos discursos,

3 A análise dessas gravuras é parte da tese de doutorado A competição entre os discursos e as artes na Historia de la conquista de México de Dom Antonio de Solís apresentada ao Programa de Pós-Graduação em Língua Espanhola e Literaturas Espanhola e Hispano-Americana do Departamento de Letras Modernas da Faculdade de Filosofia, Letras e Ciências Humanas da Universidade de São Paulo (FFLCH-USP). A discussão sobre a competição entre as artes da História e da Gravura, que é proposta nesse artigo, é desenvolvida de forma mais ampla na tese, defendida em 2014.

4 As etapas, com base nas propostas de Leon Battista Alberti em Da Pintura (2009), dividem-se em circunscrição, composição e recepção de luz.

5 A primeira edição do Tratado da Gravura foi publicada em Paris em 1643. A edição utilizada é a traduzida do francês para o português por José Joaquim Viegas Menezes sob auspício e ordem de Dom João VI, publicada em Lisboa em 1801. O arcaísmo da edição é mantido e os grifos são de nossa autoria.

6 De certa forma, a gravura antecipa a "reprodutibilidade técnica" da obra de arte, de acordo com as reflexões de Walter Benjamin. Essa reprodutibilidade, no caso dos livros, faz com que a imagem seja reproduzida sem controle por parte dos gravadores e editores. Atualmente, após a gravação, as matrizes são inutilizadas quando o artista chega ao número máximo da tiragem, que é explicitada em cada exemplar, assinado e numerado, com menção ao número total de cópias.

7 A competição também é empenhada nos discursos introdutórios das edições seiscentistas, cujos autores eram os homens discretos, que legitimavam a obra e estabeleciam uma leitura regrada. Nesse espaço, os discretos disputam entre si para fazer brilhar a obra e seu texto, assim como o historiador disputa com o 'herói' das façanhas narradas para que sua escrita brilhe tanto ou mais que a espada empreendida nas batalhas. A tópica da competição entre as armas e as letras faz-se presente tantos nos discursos introdutórios

Revista Letras, como na própria narração da história, estendendo-se para a competição entre o texto e a imagem.

Curitiba, UFPR,

n. 97 , pp. 106-129,

jan./jun. 2018.

ISSN 2236-0999

(versão eletrônica) 
elas não devem ser consideradas como ilustrações porque este conceito inexiste para o século XVII.

A História ${ }^{8}$ como gênero deve expressar o particular $^{9}$ e tem como função narrar a verdade. As gravuras são ornamentos dessa verdade particular, narrada e ajuizada pelo historiador, sem, necessariamente, terem o papel de fidelidade aos fatos, pois, se são fiéis, o são ao discurso histórico que retratam, uma vez que buscam a emulação dele. Em seu tratado Da Pintura, Leon Battista Alberti (2009, p. 97) questiona: "Quem pode duvidar então que a pintura seja mestra ou, ao menos, não pequeno ornamento de tudo?”. As gravuras da Historia de Solís são apresentadas como ornamentos, ornatos que enriquecem a narração porque são como um instrumento através do qual e no qual a beleza vem à luz. Ao imitar o discurso historiográfico, a gravura alimenta e sustenta o que é narrado, confirma a verdade e promove sua persuasão. Por essa razão, as imagens que adornam a Historia de Solís são pensadas como ornatos, efeitos de maravilha que produzem afetos ${ }^{10}$ pretendidos segundo seus decoros.

O discurso histórico seiscentista é fabricado pela arte, pois narrar os feitos construídos como memoráveis é descrevê-los, portanto retratá-los, ou seja, fazer com que o leitor possa vê-los. A partir de técnicas descritivas, cujo efeito é a evidentia, ${ }^{11}$ as matérias narradas se tornam vistas, não apenas lidas, sendo entendidas como belas. Nas edições enriquecidas com gravuras, as matérias lidas e vistas se desdobram

8 Evitamos mencionar o termo Crônica, bem como "Crônicas das Índias", para nos referir à História, como é comum no campo dos estudos coloniais da área de História e Letras, por adequação à leitura proposta no artigo. O gênero histórico é composto a partir de diversos subgêneros como, por exemplo, a própria crônica, que narra a história dos tempos sem ajuizar os fatos. Cada subgênero segue preceitos expostos nas retóricas e seus manuais, ademais eles diferem entre si e alguns, quando reunidos, compõem uma História, que, evidentemente, não é uma Crônica. Essas ponderações encontram eco nas reflexões de Alfonso Mendiola (2003), que adverte sobre o fato de as "Crônicas das Índias" serem, normalmente, utilizadas apenas como fonte de informação sem as implicações de sua codificação retórica. Crônicas e Histórias seiscentistas não tinham como preocupação primordial a informação, mas o juízo de uma verdade particular, de acordo com o que se entendia e se considerava verdade na época.

9 Segundo Aristóteles (2007, p. 54), na Poética, o historiador e o poeta diferem pelo fato de "um relatar o que aconteceu e outro o que poderia acontecer. Portanto, a poesia é mais filosófica e tem um carácter mais elevado que a História. É que a poesia expressa o universal, a História o particular. O universal é aquilo que certa pessoa dirá ou fará, de acordo com a verossimilhança ou a necessidade, e é isso que a poesia procura representar, atribuindo, depois, nomes às personagens. O particular é, por exemplo, o que fez Alcibíades ou o que lhe aconteceu."

10 Segundo Miguel de Salinas (1980, p. 156), em "Retórica de la lengua castellana", afeto "es un movimiento o perturbación que más propiamente decimos las pasiones del ánima, porque según las mudanzas que se ofrecen, así se inclinan a dolor, alegría, misericordia, crueldad, amor, odio, etc. De estas ninguno carece, pero si se mueven con razón son virtudes y si no, son vicios".

11 O efeito da evidentia faz com que o leitor tenha a impressão de que as coisas não estão sendo apenas descritas, mas acontecendo diante de seus olhos. Frei Luis de Granada (1793, p. 396) conceitua evidentia, que ele chama de energía, a partir de Quintiliano: "Grande virtud es decir las cosas de que hablamos claramente, y de un modo que parezca que se miran. Lo cual unas veces se hace con breve razonamiento, otras con largo [...]".Para João Adolfo Hansen (2006, p.93), o efeito de evidentia, ou enargeia, que ao pé da letra significa "vividez", intensifica a clareza dos ornatos aplicados, tornando-os mais nítidos. A evidentia é definida, a partir das leituras de Cícero, Quintiliano e o Anônimo da Retórica a Herênio, como descriptio produtora de pathos que torna a causa como que presente, por isso eficaz. Esse efeito deve ser alcançado a partir de três modos: pessoa, lugar e tempo. Deve-se descrever uma pessoa como se ela estivesse presente, um lugar como se pudéssemos vê-lo e o tempo como se o presente fosse o passado. 
FreIRE, D. J.

Imitação e

emulação entre o discurso histórico e a arte pictórica na representação da prática

dos sacrifícios no templo de Viztziliputztli

em uma competição entre as artes da História e da Gravura, ou seja, entre o texto e a imagem. Essa rivalidade é estabelecida pela imagem como forma de superar a narração e as descrições empenhadas pelo historiador. Assim, além de ornamento, as gravuras amplificam a narração ao competir com o discurso para superá-lo com os efeitos de docere (ensinar), delectare (agradar) e movere (persuadir).

Nessa competição, a gravura salta aos olhos do leitor - e espectador - em razão das próprias técnicas pictóricas aplicadas, principalmente a perspectiva e a recepção de luz. A perspectiva permite o julgamento tanto da proporção e simetria perfeitas do desenho, como, por exemplo, na composição de uma cidade, quanto à semelhança dos elementos retratados da própria natureza. Portanto, a gravura imita não apenas o discurso do cronista como também a natureza. A recepção de luz é uma técnica decisiva para a perspectiva, pois, dependendo de onde se coloca a luz, os elementos ficam mais claros ou mais escuros, criando a ilusão de profundidade na imagem. A luz e a sombra também fazem com que as coisas pareçam possuir relevo, que é o efeito mais louvado por Alberti $(2009$, p. 121) porque é o que confere maior prestígio ao pintor. Com a aplicação desses preceitos pictóricos, entre outros, a gravura afeta o leitor - e espectador - de forma mais vigorosa, pois, ao imitar não apenas o discurso como também a natureza, ensina, agrada e persuade com mais eficácia e brilho. Aliás, com essas técnicas, a imagem, com seu brilho, compete com a clareza do estilo do historiador, afinal, a ausência de estilo adequado é a justificativa de Solís para se dedicar à narração das façanhas de Hernán Cortés para conquistar o México e a Nova Espanha. ${ }^{12}$

\section{A imitação do templo de Viztzilipuztli ${ }^{13}$}

As gravuras do templo Viztzilipuztliimitam a narração, bem como a descrição, empenhada por Dom Antonio de Solís na Historia de la conquista de México. As imagens imitam os lugares-comuns, topoi, conhecidos, bem como compartilhados, das descrições de lugar preceituados pelas artes retóricas para representar imagens desconhecidas e estranhas para o leitor do século XVII sobre o México e os costumes dos povos que aí viviam. A imagem do templo direciona o leitor - e espectador para a prática do sacrifício, que surge na sequência a partir da aplicação do recurso do zoom da objetiva e do foco de um telescópio. Ou seja, na gravura do templo é retratada a prática do sacrifício, que é recortada e ampliada na imagem seguinte. Esse recurso visa acercar o leitor e espectador a uma determinada cena. Abaixo, as gravuras do templo e do sacrifício comprovam o procedimento de ampliação a partir do zoom.

12 Nos primeiros capítulos de sua obra, Solís (1684, I, II, p.4) afirma que a conquista da Nova Espanha ainda não possui uma História digna de seus grandes feitos, pois ainda lhe falta o estilo elevado do gênero histórico, como o que foi empenhado pelo Inca Garcilaso de la Vega na História do Peru, cuja narração é ajuizada como "tan puntual en las noticias, y tan suave, y ameno en el estilo". 13 Essa é a grafia usada na narração da Historia de la conquista de México de Dom Antonio de Solís,

Revista Letras, atualmente se grafa Huitzilopochtli. Procuramos manter, sempre que possível, a grafia utilizada por Solís.

Curitiba, UFPR,

n. 97 , pp. 106-129,

jan./jun. 2018.

ISSN 2236-0999

(versão eletrônica) 


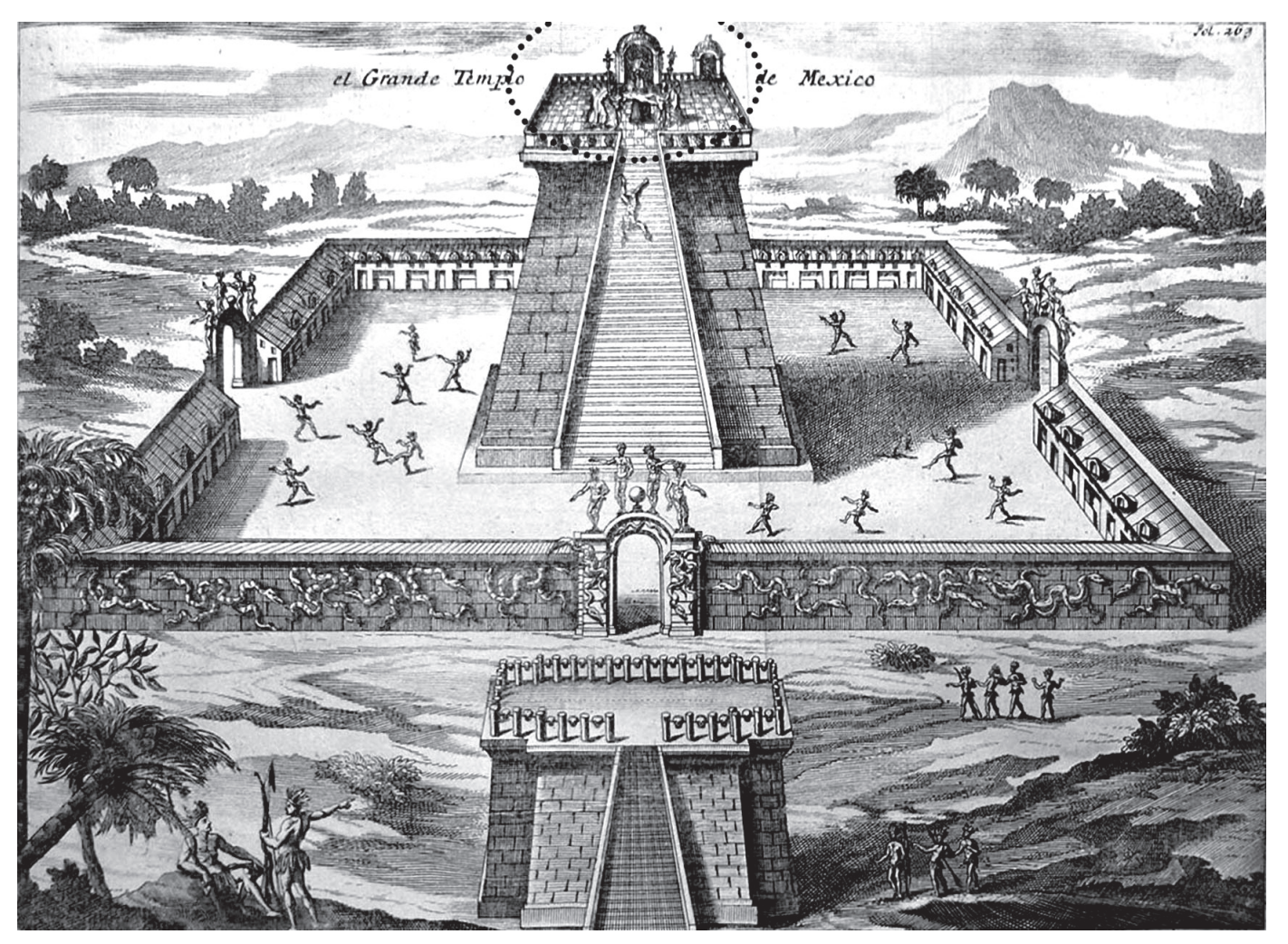

112

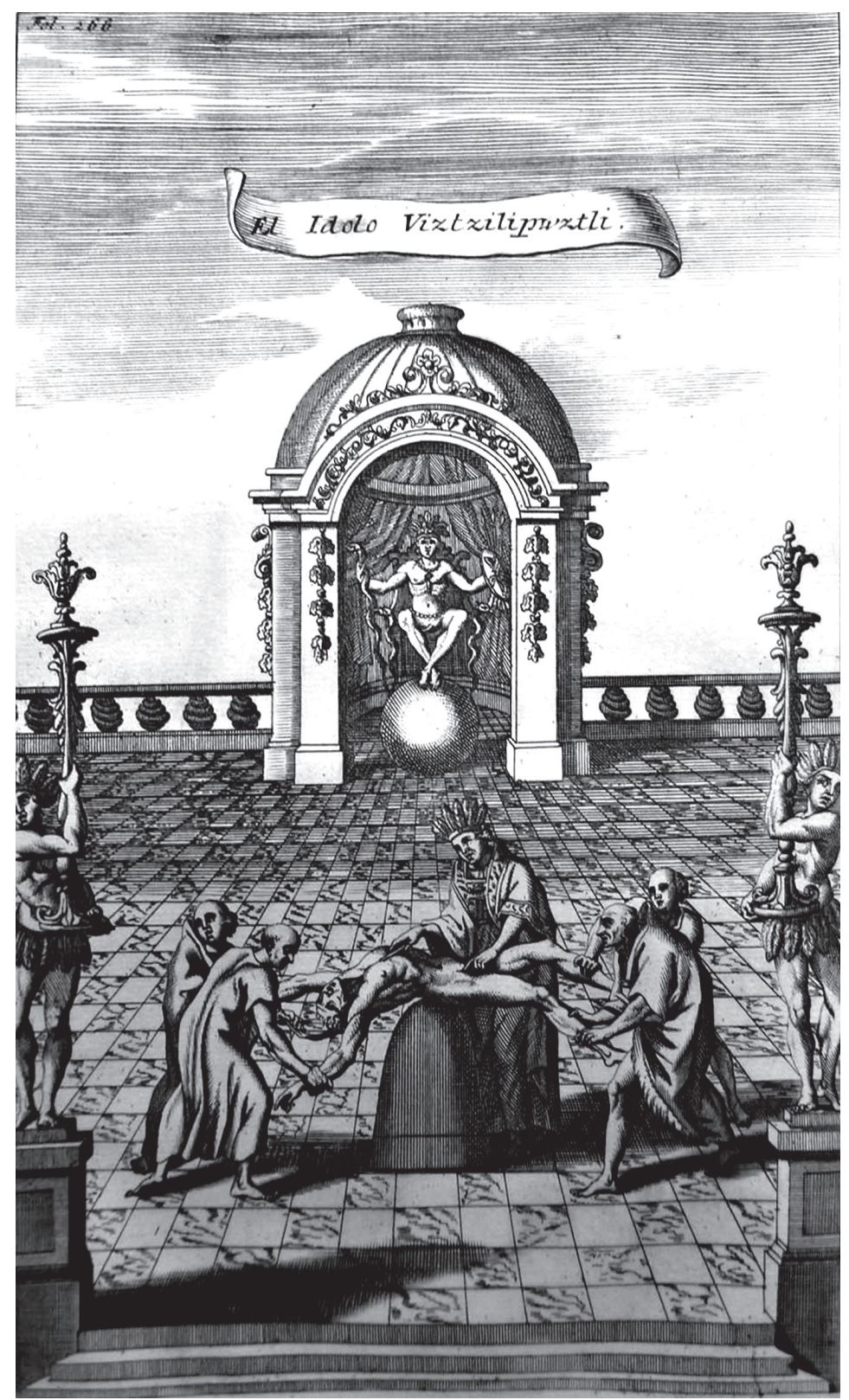


FreIRE, D. J.

Imitação e

emulação entre o discurso histórico e a arte pictórica na representação da prática

dos sacrifícios no templo de Viztziliputztli

A partir desse procedimento, o leitor - e espectador -, após ser levado para o templo, é conduzido, na sequência, ao seu topo, onde acontece o sacrifício. Ao descrever o templo de Viztzilipuztli, Solís aplica a censura tanto da religião professada pelos povos indígenas como também de seus sacerdotes. Também é nesse momento da narração que o cronista expõe e ajuíza sobre as fontes que segue para descrever os espaços de culto de Tenochtitlan: ${ }^{14}$

Los Templos (si es licito darles este nombre) se levantavan sumptuosamente sobre los demàs Edificios: y el mayor, donde residia la suma Dignidad de aquellos inmundos Sacerdotes, estava dedicado al Idolo Viztzilipuztli, que en su lengua significava Dios de la Guerra, y le tenian por el Supremo de sus Dioses. Primacia de que se infiere, quanto se precisava de Militar aquella Nacion. El vulgo de los Soldados Españoles le llamava Huchilobos, tropezando en la pronunciaciõ : y assi le nombra Bernal Diaz del Castillo, hallando en la Pluma la misma dificultad. Notablemẽte discuerdan los Autores en la descripcion de este sobervio Edificio. Antonio de Herrera se conforma demasiado con Francisco Lopez de Gomara : los que le vieron entonces, tenian otras cosas en el cuydado, y los demàs tiraron las lineas à la voluntad de su consideracion. Seguimos al

Padre Joseph de Acosta, y à otros Autores de los mejor informados. (SOLÍS, 1684, III, XIII, p. 236). ${ }^{15}$

A justificativa pela escolha de suas fontes é uma das formas de Solís para estabelecer a fé, ou seja, a credibilidade, pelo que descreve e narra. Desse modo, Bernal Díaz del Castillo, por pertencer ao vulgo dos soldados, nomeia ao deus Viztzilipuztlide Huchilobos, ${ }^{16}$ transpondo para a pluma, ou seja, a escrita, a mesma dificuldade da pronunciação, razão pela qual não é digno de ser seguido. Já Antonio de Herrera se conforma demasiado com Francisco López de Gómara. Além deles, aqueles que estiveram presentes na cidade do México e viram o templo 'tenian otras cosas en el cuydado'; outros ainda expuseram o templo ao sabor de sua própria consideração. Em razão desses juízos, a obra do padre

14 Lembramos que os templos de Tenochtitlan são chamados por Hernán Cortés de mesquitas, em uma evidente relação com os espaços religiosos dos muçulmanos. Sobre o templo de Viztzilipuztli, Cortés (1985, p. 134) afirma: "[...] y entre estas mezquitas hay una que es la principal, que no hay lengua humana que sepa explicar la grandeza y particularidades de ella, porque es tan grande que dentro del circuito de ella, que es todo cercado de muro muy alto, se podía muy bien hacer una villa de quinientos vecinos; [...] Hay bien cuarenta torres muy altas y bien obradas, que la mayor tienen cincuenta escalones para subir al cuerpo de la torre; la más principal es más alta que la torre de la iglesia mayor de Sevilla.".Para Todorov (2006), o mecanismo de nomear espontaneamente os lugares de culto como "mesquitas" se propaga para designar qualquer templo destinado a uma religião não-cristã. Os conquistadores espanhóis "quando descobrem uma cidade um pouco mais importante, logo a chamam 'o grande Cairo". Para o crítico, "as ilustrações da época dão igualmente um bom testemunho dessa projeção do familiar (por mais estranho que pareça) sobre o desconhecido." Grifos nossos.

$15 \mathrm{O}$ arcaísmo da edição princeps foi mantido. Os grifos são nossos em todas as citações da Historia de Solís.

16 Nesse exemplo sobre a aproximação que Bernal Díaz faz do nome Viztzilipuztli,vemos como o reconhecimento de uma palavra, totalmente estranha aos ouvidos, é feito por aproximação ao

Revista Letras, conhecido, nesse caso com "lobos".

Curitiba, UFPR,

n. 97 , pp. 106-129,

jan./jun. 2018.

ISSN 2236-0999

(versão eletrônica) 
José de Acosta ${ }^{17}$ é a eleita como fonte principal, além de outras mais bem informadas, as quais não são nomeadas. Por ser, declaradamente, fonte seguida por Solís, a obra de Acosta torna-se fundamental para compreender a representação do sacrifício na gravura seguinte à do templo. É provável que o artífice e o gravador tenham recorrido à Historia do padre para retratar essa prática, pois Solís se nega a descrevê-la por considerar que superstições, indecências e obscenidades mancham a narração da História.

$\mathrm{Na}$ descrição dos templos da cidade do México, Solís os qualifica de suntuosos, principalmente se comparados a outros edifícios, assim, os espaços destinados aos cultos dos deuses destacam-se pelo luxo, pela pompa e magnificência. No maior deles, destinado a Viztzilipuztli, residiam os sacerdotes, qualificados de imundos porque não respeitam as regras de decoro e decência que se deve ter nos cultos de acordo com a conduta cristã. $O$ adjetivo imundo estende-se como juízo das próprias práticas, as quais devem ser vistas como repugnantes pelo leitor. Sobre o ídolo, Solís afirma que Viztzilipuztli significava na língua asteca deus da guerra. ${ }^{18} \mathrm{~A}$ comparação do ídolo com Marte intensifica e amplifica o poder militar dos povos indígenas sob o comando de Moctezuma, o que contribui para singularizar e abrilhantar a conquista de Hernán Cortés e seu exército.

Após a censura sobre os sacerdotes, Solís descreve, de forma minuciosa, a entrada do templo de Viztzilipuztli evidenciando a repugnância que causa tal visão:

Su primera mansion era una gran Plaza en quadro, con su Muralla de Silleria, labrada por la parte de à fuera con diferentes lazos de Culebras encadenadas, que davan horror al Portico, y estavan alli con alguna propriedad. Poco antes de llegar à la Puerta principal estava un Humilladero, no menos horroroso. Era de piedra con treinta gradas de lo mismo, que subian à lo alto; donde avia un genero de Azutea prolongada, y fixos en ella muchos Troncos de crecidos Arboles, puestos en hilera : tenian estos sus taladros iguales à poca distancia, y por ellos passavan de un Arbol à otro diferentes baras, ensartando cada una, por las sienes, algunas Calaberas de hombres sacrificados; cuyo numero (que no se puede referir sin escandalo) tenian siempre cabal los Ministros del Templo; renovando las que padecian algun destrozo con el tiempo. Lastimoso Tropheo, en que manifestava su rencor el Enemigo del Hombre : y aquellos Barbaros le tenian à la vista sin algun remordimiento de la Naturaleza, hecha devocion la inhumanidad, y desaprovechada, en la costũmbre de los ojos, la memoria de la muerte.(SOLÍS, 1684, III, XIII, p. 236/237).

17 Padre José de Acosta foi membro da Companhia de Jesus, como o próprio Solís, portanto, a escolha não é aleatória, pois ambos pertenceram à mesma ordem religiosa. A Historia Natural y Moral de las Indias do padre Acosta foi publicada em Sevilha em 1590.

18 A comparação empenhada por Dom Antonio de Solís está ausente de sua principal fonte: a Historia do padre José de Acosta, que afirma que o nome Viztzilipuztli significa "siniestra de pluma relumbrante". É difícil afirmar quanto a fonte de Solís para tal comparação. Eduardo Natalino dos Santos (2002, p. 219), ao tratar sobre esse deus indígena, expõe que frei Bernardino Sahagún o caracteriza como o principal deus que adoravam os mexicas e, explicitamente, relaciona-o a Hércules. 
Freire, D. J.

Imitação e

emulação entre o discurso histórico e a arte pictórica na representação

da prática

dos sacrifícios no templo de

Viztziliputztli
A descrição põe, com evidentia, ${ }^{19}$ a imagem da entrada do templo diante dos olhos do leitor, buscando afetá-lo com o horror dessa visão. Esse sentimento é provocado, principalmente, pelo detalhamento de adornos da muralha, como os laços de cobras encadeadas que se estendem até o pórtico, e intensificado pela sequência de caveiras do 'Humilladero'. A disposição das caveiras dos homens sacrificados é ajuizada por Solís como 'Lastimoso Tropheo', pois impõe aos olhos a memória constante e insistente da morte até que esta inimiga do homem se torne costumeira. Essa descrição é suficiente para que Solís ajuíze os indígenas como bárbaros e evidencie sua inumanidade, sem que, para isso, se comprometa a narrar o sacrifício. Esses detalhes podem ser vistos na gravura, como mostra o recorte abaixo.

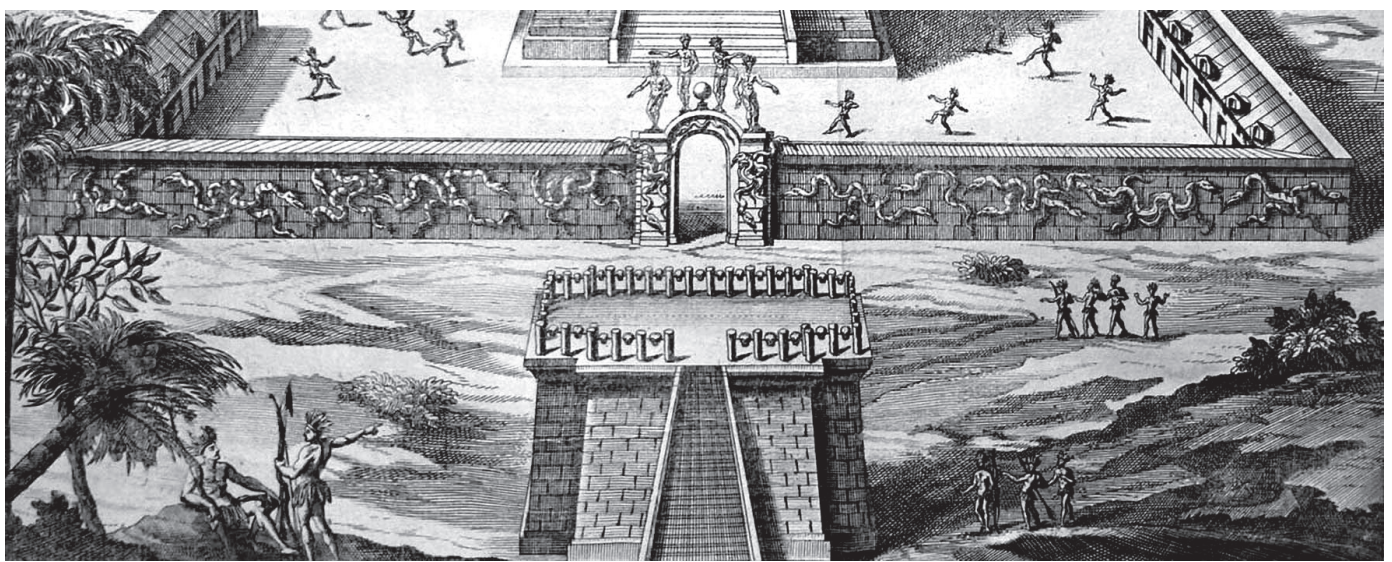

Acima, detalhes da gravura em que se destacam, respectivamente, o muro, o pórtico e o "Humilladero".

$\mathrm{Na}$ representação da entrada do templo, vemos as particularidades evidenciadas por Solís, como o muro talhado de cobras encadeadas, em que se destaca o pórtico, que tem a sua frente o "Humilladero". Na imagem, as cobras ganham movimento e intensificam o horror aos olhos do espectador, pois provocam a sensação de que se erguem como se estivessem vivas. Esse efeito é alcançado pela técnica de luz e sombra, que, de acordo com leitura do tratado de Alberti, é capaz "de produzir os efeitos de maior e menor relevo, de criar, em suma, a ilusão da realidade tridimensional” (apud GRAYSON, 2009, p. 61). Esses ornamentos da entrada em pleno movimento são intensificados pela inserção de personagens indígenas de ambos os lados do 'Humilladero'. Como destacado a seguir.

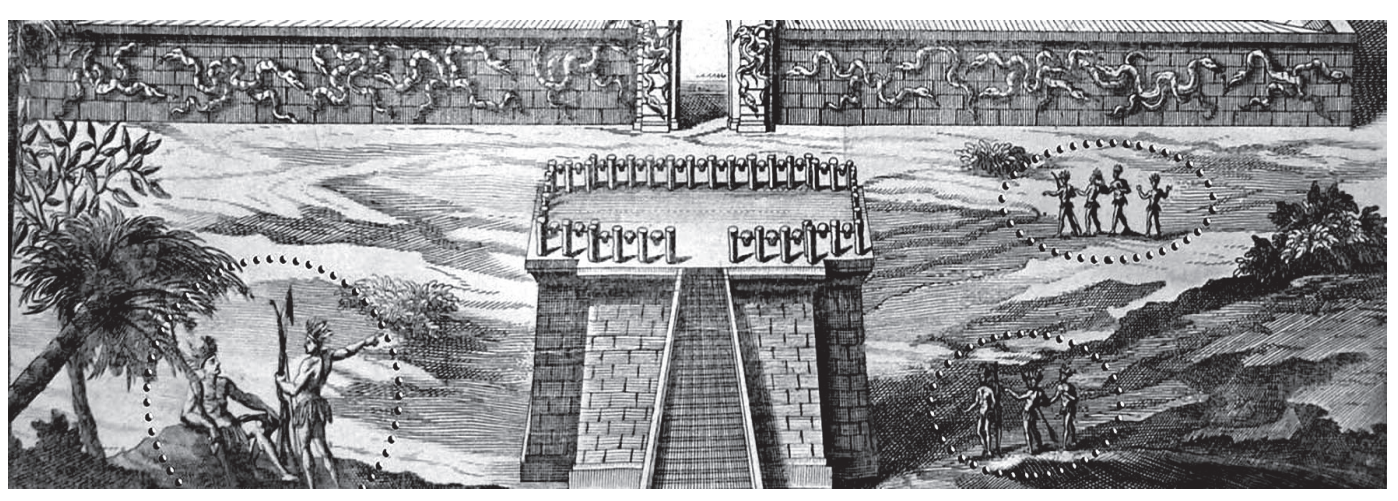

19 Conforme indicado na nota 10, o efeito da evidentia, considerada uma virtude retórica, faz com que o leitor tenha a impressão de que as coisas não estão sendo apenas descritas, mas acontecendo diante de seus olhos.
Revista Letras, Curitiba, UFPR, n. 97 , pp. 106-129,

jan./jun. 2018. ISSN 2236-0999

(versão eletrônica) 
Do lado esquerdo, em primeiro plano, um indígena está sentado em uma pedra e conversa com outro que aponta para o alto da pequena pirâmide, assim direciona o olhar do espectador para as 'horrendas caveiras', de acordo com o juízo de Solís. Ambos carregam suas armas, mas são retratados em posição de repouso com o semblante sereno apesar dos quadros ao redor, como as caveiras e, na imagem completa, o sacrifício no topo da pirâmide maior. Quando comparados o discurso e a gravura - o texto e a imagem -, vemos que essa inserção faz com que o espectador seja afetado pelo horror de forma mais vigorosa, pois tem retratadas, diante de seus olhos, a calma e a serenidade dos dois indígenas frente àquelas representações que evidenciam a barbárie e a inumanidade que Solís lhes atribui. Essa sensação é reforçada pelos dois grupos de indígenas do lado direito que também são figurados com suas armas e com atitudes calmas e serenas. A inserção dessas personagens, ausentes da descrição do cronista, intensifica o horror para os olhos físicos, se comparados ao que o olho intelectual do juízo lê pelas tintas de Solís. Essa observação corrobora a ideia de competição entre o discurso historiográfico e a arte pictórica, pois a imagem transcende o que é narrado e descrito no texto ao inserir elementos e detalhes ausentes da descrição do cronista, como os grupos de indígenas. Ao comparar texto e imagem, a Gravura brilha mais que a História, pois provoca os afetos de horror de forma mais vigorosa.

A figura do indígena que aponta para o 'Humilladero' direciona o olhar do espectador para seu topo, onde estão as caveiras dos sacrificados. Em um movimento ascendente, nosso olhar é levado para a pirâmide maior, onde vemos a prática do sacrifício. Essa técnica pictórica aplicada na gravura imita o movimento do olhar, que pode ser considerado natural ou até mesmo cristão. As representações religiosas, bem como as celebrações, levam os fiéis, constantemente, a mirar do baixo para o alto, do humano ao divino. No entanto, na gravura, ao contrário do que acontece nas pinturas religiosas, o artífice rompe a expectativa do espectador, principalmente cristão, pois, no lugar mais elevado, em vez do sublime, há a representação do horror. Esse horror fica mais intenso do que no topo da pirâmide menor, onde, nessa relação, há apenas 'singelas' caveiras quando comparadas aos corpos no topo da pirâmide maior. Dessa forma, se estabelece a competição entre os horrores dos costumes indígenas, bem como entre o discurso e a gravura. A imagem assume seu lugar de primazia porque, ao contrário do cronista ${ }^{20}$, $\mathrm{o}$ artífice e o gravador saciam a curiosidade do leitor e expõem, sem pudores, uma cena de sacrifício no topo da pirâmide, onde um corpo é aberto enquanto outro despenca pelas escadas. A representação é central na gravura, bem como o movimento do olhar, como mostra o recorte inserido na sequência.

20 Como comentado na introdução, Dom Antonio de Solís não descreve o sacrifício porque não quer manchar o estilo de sua história. Ao decidir inserir o sacrifício na gravura, tanto o editor como o desenhista evidenciam uma disputa com o texto de forma a afetar o leitor de forma mais intensa, além de saciar sua curiosidade com temas caros à conquista e colonização: o sacrifício e a possibilidade do canibalismo. 
FreIRE, D. J.

Imitação e

emulação entre o discurso histórico e a arte pictórica na representação da prática

dos sacrifícios no templo de Viztziliputztli

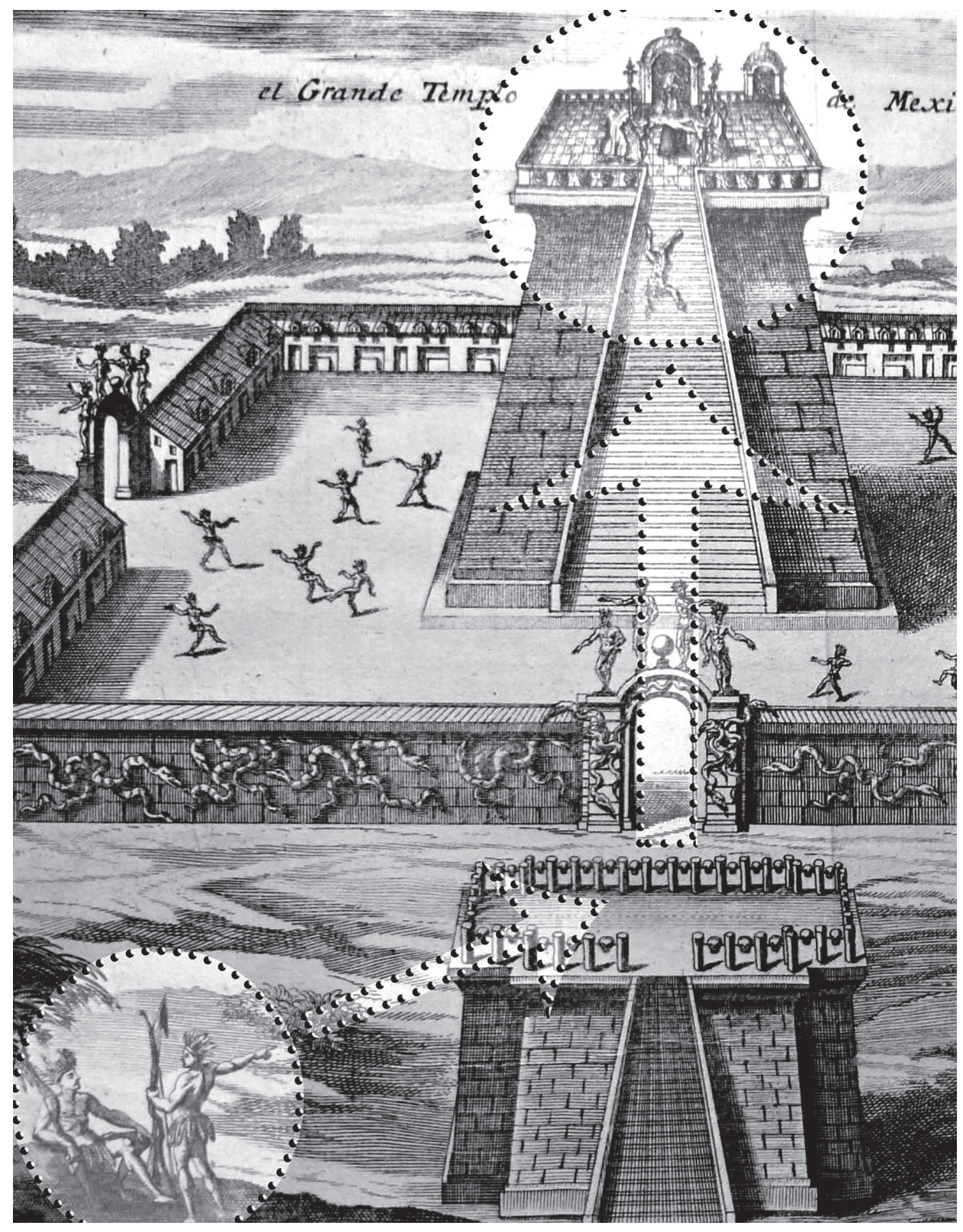

\section{A imitação da prática do sacrifício e da 'capilla' de Viztzilipuztli}

No centro e interior do templo, está edificada, a céu aberto, uma meia pirâmide, chamada por Solís de 'gran Maquina de piedra' com "los tres lados pendientes; y en el otro labrada la Escalera" com 120 degraus, que marcam o quão alto era a 'máquina'. O uso de tal termo marca que os sacrifícios eram realizados em grande escala, afinal, em cada evento desse porte eram sentenciados mais de 50 prisioneiros, conforme afirma em sua história o padre Acosta. No topo das escadas, em um pavimento de quarenta pés, adornado com jaspes e por um "pretil con sus Almenas retorcidas, à manera de caracoles", estão a pedra pontiaguda onde sacrificam os 'miserables' e duas 'capillas'. A maior é dedicada ao ídolo Viztzilipuztli e a menor a Tlaloch, que, segundo Solís, era de todo semelhante ao seu companheiro. A imitação da descrição do pavimento no alto da pirâmide e sua composição pode ser vista na gravura posterior à do templo que expõe o sacrifício em primeiro plano tendo como pano de fundo a 'capilla' de Viztzilipuztli.

Revista Letras, Curitiba, UFPR, n. 97, pp. 106-129,

jan./jun. 2018. ISSN 2236-0999

(versão eletrônica) 


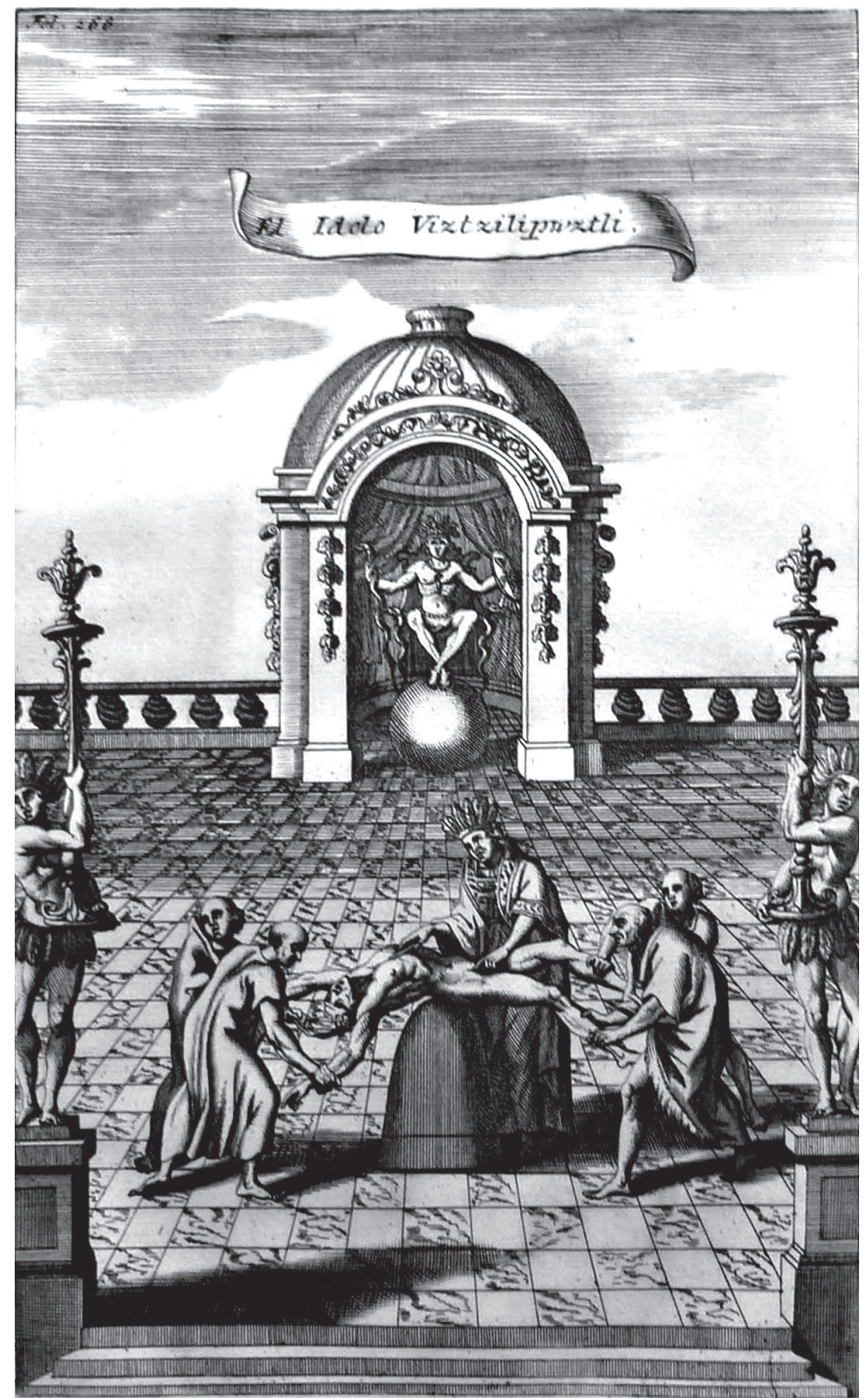

Imitando a descrição de Solís, o artífice insere ao final da escada, no extremo de cada lado, duas estátuas de mármore com braços que expressam força e sustentam grandes candelabros de 'hechura extradordinaria'. Na composição da gravura, ambas as figuras se encarregam de delimitar a moldura da cena que acontece no centro do pavimento e que tem a 'capilla' em perspectiva. Seus corpos musculosos expressam a força, que é evidenciada no discurso do cronista, e tanto a vestimenta como a nudez seguem os preceitos pictóricos que fazem ver, e reconhecer, os povos do Novo Mundo. Ademais, como na imagem do templo, o artífice acrescenta movimento às estátuas, principalmente nos gestos dos braços, nas pernas e no olhar, o que a torna mais funesta do que a descrição. Essa sensação é intensificada pelos olhos da estátua do lado direito, cujo mirar espreita, diretamente, o espectador. 
Freire, D. J. Imitação e emulação entre o discurso histórico e a arte pictórica na representação da prática dos sacrifícios no templo de Viztziliputztli
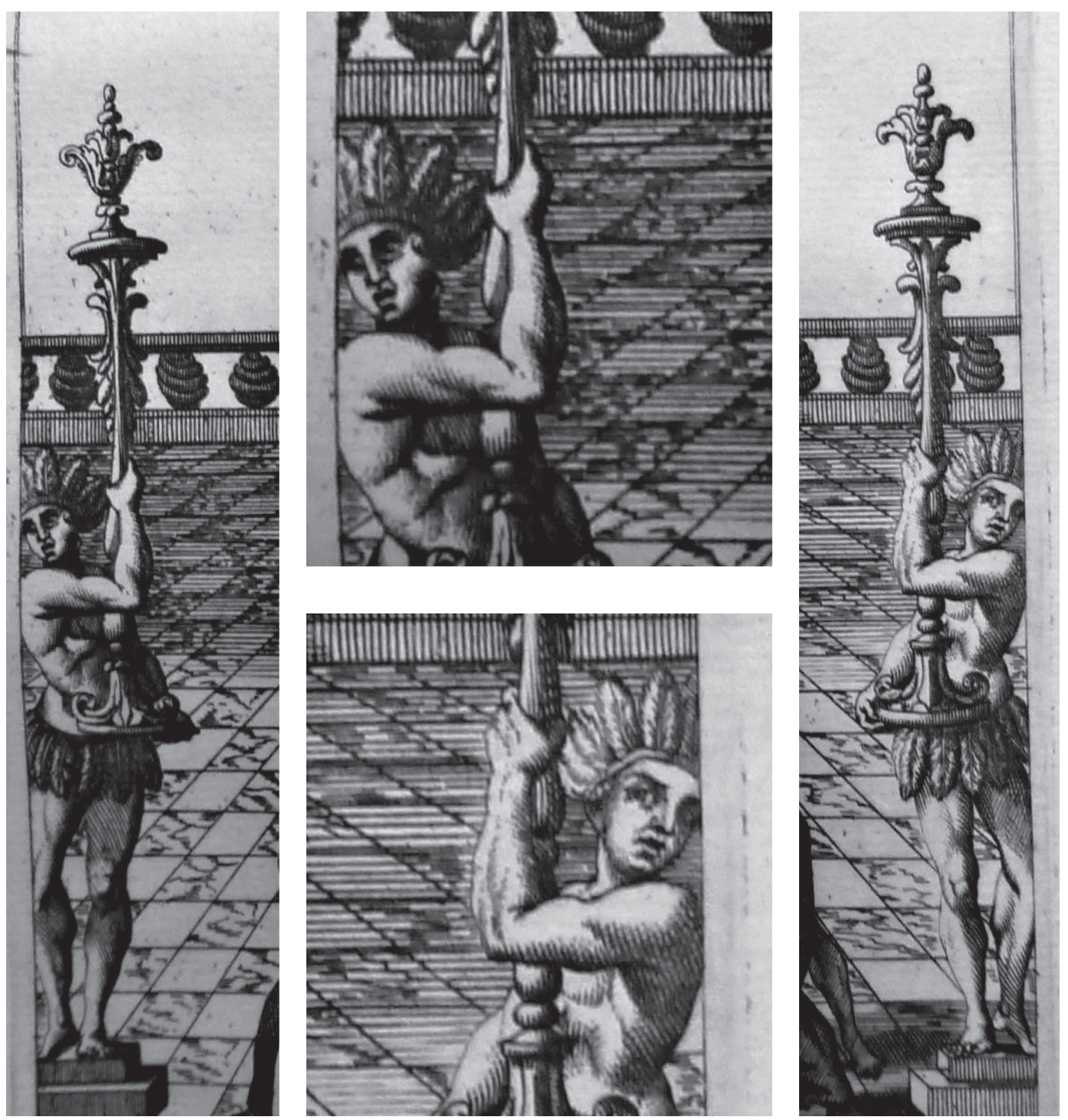

Através do movimento e do olhar de ambas as estátuas, o leitor e espectador são levados para o centro da gravura, onde se deparam com o sacrifício. A essa prática, Solís dedica poucas palavras: "Mas adelante una lossa verde, que se levantava cinco palmos del suelo, y rematava en Esquina, donde afirmavan por las espaldas al Miserable, que avian de sacrificar, para sacarle por los pechos el corazon". Apesar de o sacrifício estar representado na imagem, de forma detalhada e em primeiro plano, sua descrição está ausente do discurso de Solís. No entanto, a cena pode ser lida e 'vista', com evidência, no Capítulo 20 - "De los sacrificios horribles que usaron los mexicanos" - do quinto livro da Historia Natural y Moral de las Indias de José de Acosta. De acordo com o padre, o modo de sacrifício consistia em abrir o peito do sacrificado e arrancar o coração quando ainda estivesse vivo; depois o corpo era arremessado pelos degraus da escada, que ficavam banhados de sangue. Sobre a condução da prática e aqueles que a executavam, afirma:

[...] Lo cual para que se entienda mejor, es de saber que al lugar del sacrificio salían seis sacrificadores constituidos en aquella dignidad; los cuatro para tener los pies y manos del que había de ser sacrificado, y otro para la garganta, y otro para cortar el pecho y sacar el corazón del sacrificado. Llamaban a éstos
Revista Letras, Curitiba, UFPR, n. 97, pp. 106-129,

jan./jun. 2018. ISSN 2236-0999 (versão eletrônica) 
chachalmua, que en nuestra lengua es lo mismo que ministro de cosa sagrada; era esta una dignidad suprema, y entre ellos tenida en mucho, la cual se heredaba como cosa de mayorazgo. El ministro que tenía oficio de matar, que era el sexto de éstos, era tenido e reverenciado como supremo sacerdote o pontífice, el nombre del cual era diferente, según la diferencia de los tiempos y solemnidades en que sacrificaba, asimismo eran diferentes las vestiduras cuando salían a ejercitar su oficio en diferentes tiempos. El nombre de su dignidad era papa y topilzin; el traje y ropa era una cortina colorada a manera de dalmática, con una flocaduras por orla; una corona de plumas ricas verdes y amarillas en la cabeza, y en las orejas unos como sarcillos de oro, engastadas en ellos unas piedras verdes, y debajo del labio, junto al medio de la barba, una pieza como cañutillo de una piedra azul. Venían estos seis sacrificadores, el rostro y las manos untados de negro muy atezado; los cinco traían unas cabelleras muy encrespadas y revueltas, con unas vendas de cuero ceñidas por medio de las cabezas, y en la frente traían unas rodelas de papel, pequeñas, pintadas de diversos colores, vestidos con unas dalmáticas blancas labradas de negro. Con este atavío se revestía en la misma figura del demonio, que verlos salir con tan mala catadura ponía grandísimo miedo a todo el pueblo. El supremo sacerdote traía en la mano un gran cuchillo de pedernal, muy agudo y ancho; otro sacerdote traía un collar de palo labrado a manera de culebra. Puestos todos seis ante el ídolo, hacían su humillación, y poníanse en orden junto a la piedra piramidal que arriba se dijo que estaba frontero de la puerta de la cámara del ídolo.Era tan puntiaguda esta piedra, que echado de espaldas sobre ella el que había de ser sacrificado, se doblaba de tal suerte que dejando caer el cuchillo sobre el pecho, con mucha facilidad se abría un hombre por medio. Después de puestos en orden estos sacrificadores, sacaban todos los que habían preso en las guerras, que en esta fiesta habían de ser sacrificados, y muy acompañados de gente de guardia, subíanlos en aquellas largas escaleras, todos en renglera y desnudos en carnes, al lugar donde estaban apercebidos los ministros, y en llegando, cada uno por su orden los seis sacrificadores lo tomaban uno de un pie y otro del otro, uno de una mano y otro de otra, y lo echaban de espaldas encima de aquella piedra puntiaguda, donde el quinto de estos ministros le echaba el collar a la garganta y el sumo sacerdote le abría el pecho con aquel cuchillo, con una presteza extraña, arrancándole el corazón con las manos, y así vaheando se lo mostraba al sol, a quien ofrecía aquel calor y vaho del corazón, y 
Freire, D. J.

Imitação e

emulação entre o discurso histórico e a arte pictórica na representação da prática

dos sacrifícios no templo de Viztziliputztli luego volvía al ídolo, y arrojábaselo al rostro; y luego el cuerpo del sacrificado le echaban rodando por las gradas del templo con mucha facilidad, porque estaba la piedra puesta tan junto a las gradas que no había dos pies de espacio entre la piedra y el primer escalón, y así con un puntapié, echaban los cuerpos por las gradas abajo.[...] (ACOSTA, 1962, V, XX, p. 251-252). ${ }^{21}$

Da longa descrição, o artífice e o gravador encenam a parte que nos parece mais crucial: o momento de ação do 'supremo sacerdote', quando o sacrificado está na posição final para ter o peito aberto e seu coração arrancado. Essa cena afeta de forma mais contundente o leitor e o espectador, pois intensifica o horror de tal prática, sentimento que está evidenciado, repetidamente, na descrição que Solís empenha do templo de Viztzilipuztli. Além da ação, a gravura imita aspectos da vestimenta e da postura dos sacerdotes que, na representação, são reduzidos a cinco e não seis como narra Acosta. Ainda que o número seja distinto, as cinco ações são figuradas na imagem. Do lado direito, dois seguram as pernas do sacrificado enquanto do esquerdo dois seguram os braços, sendo que um destes é quem coloca o colar 'de palo labrado a manera de culebra' na garganta do sacrificado, como mostra o recorte abaixo.

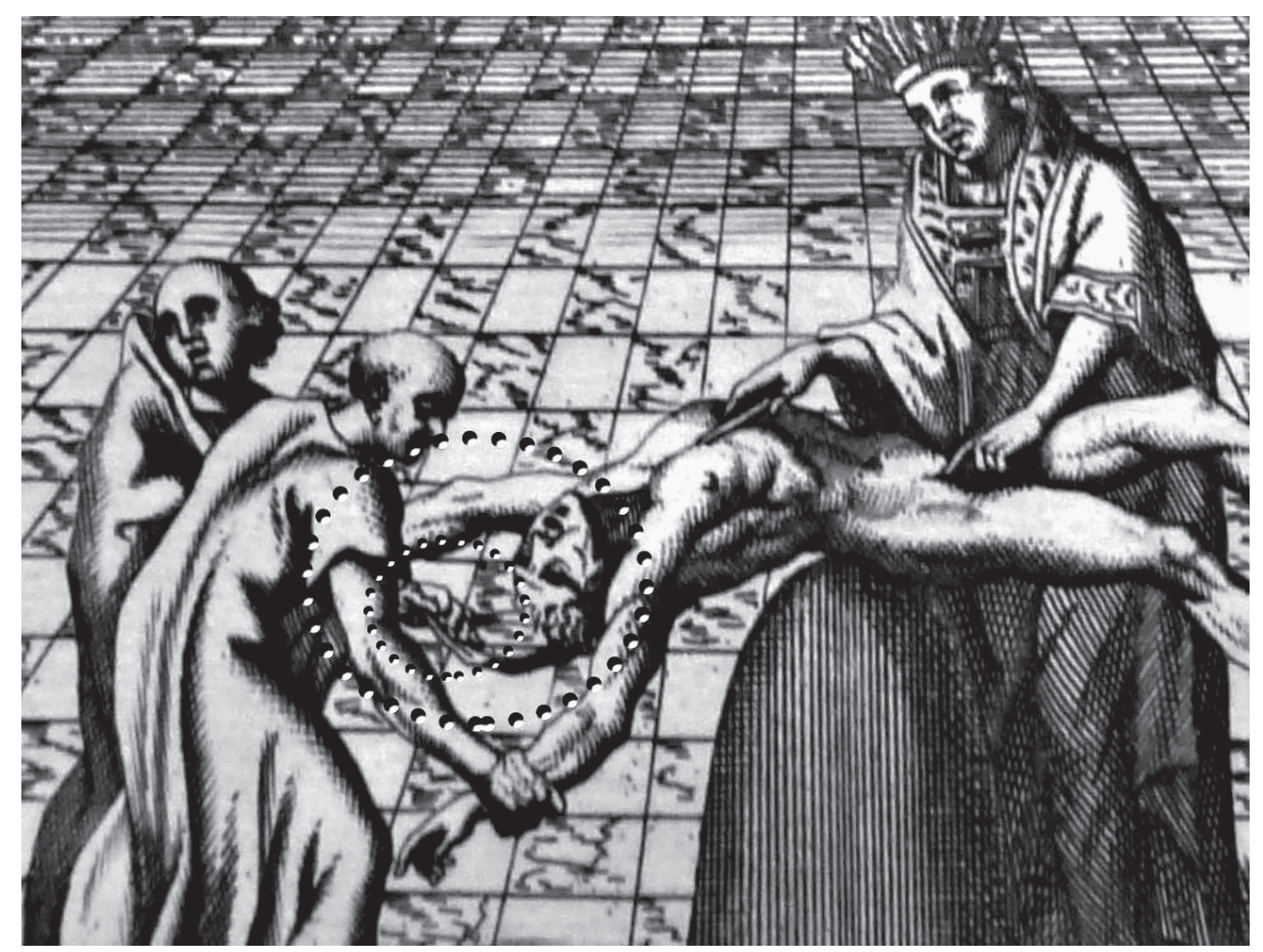

Além da ação dos sacrificadores, as vestimentas imitam, com apuro, a descrição de Acosta; assim, o 'supremo sacerdote' traja uma túnica de mangas

21 A edição utilizada da Historia Natural y Moral de las Indias do padre José de Acosta é a preparada por Edmundo O’Gorman, publicada pela Fondo de Cultura Económica em 1962. Grifos nossos. Esse fragmento comprova a competição empenhada por editor, desenhista e gravador ao decidirem inserir na edição uma gravura com ações ausentes da narração e descrição da Historia de Dom Antonio de Solís.
Revista Letras, Curitiba, UFPR, n. 97 , pp. 106-129,

jan./jun. 2018. ISSN 2236-0999 (versão eletrônica) 
amplas e curtas com adornos nas bordas, na cabeça leva uma coroa de plumas e nas orelhas uma argola de ouro. Os outros trajam túnicas brancas mais simples e levam uma espécie de faixa de couro na cabeça que, na imagem, faz com que pareçam calvos; na parte mais baixa, perto do pescoço, vemos os cabelos encrespados e revoltos. O corpo do sacrificado é figurado com uma leve inclinação para trás em função de estar apoiado sob a pedra pontiaguda e puxado pelo colar no pescoço. Essa curvatura facilita o trabalho do 'supremo sacerdote' que apenas deixa 'caer el cuchillo sobre el pecho' para abrir um homem ao meio. Esses detalhes e as ações, ausentes da Historia de Solís e narradas por José de Acosta em sua Historia Natural, podem ser vistos nos recortes a seguir.
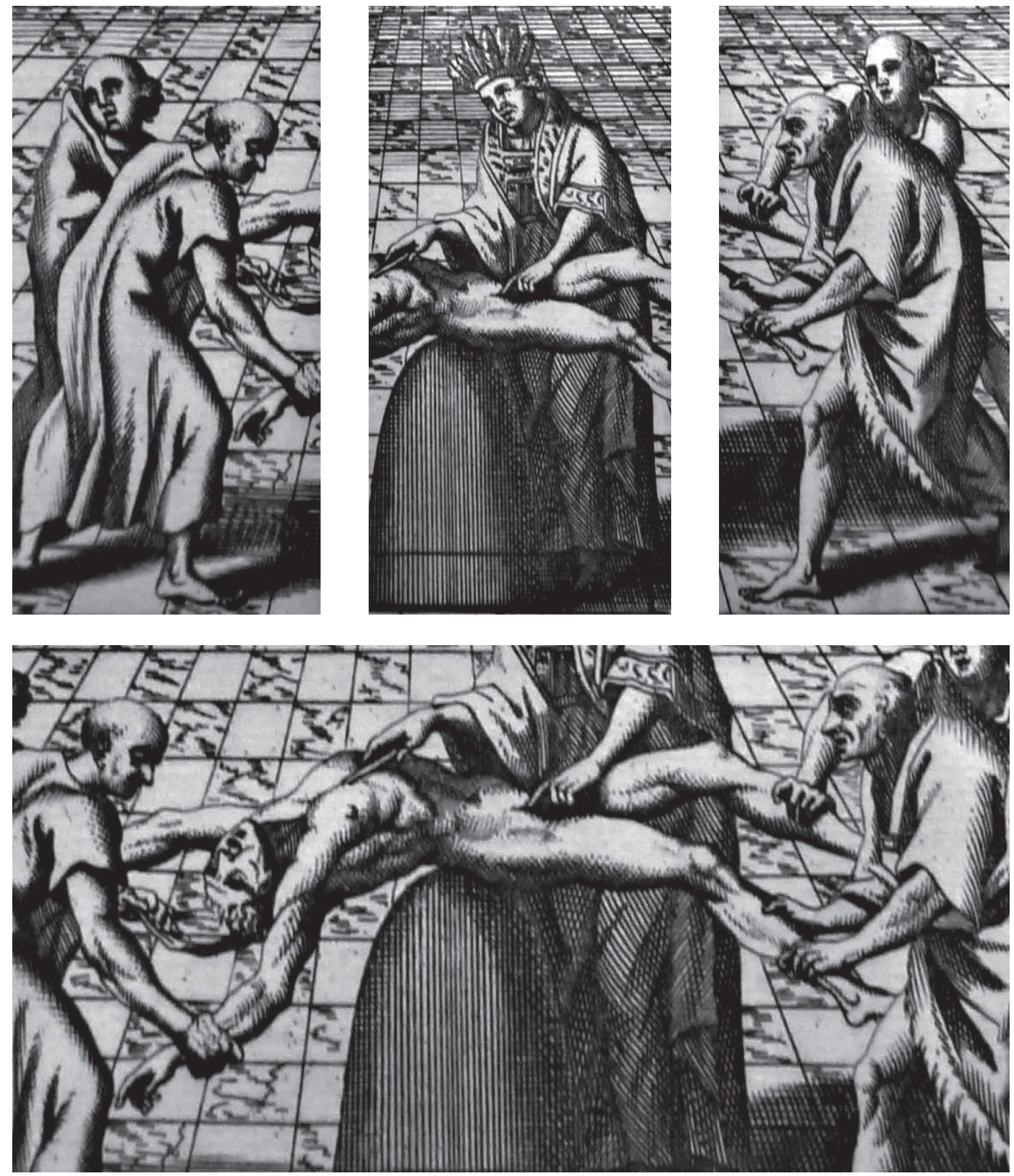

A prática do sacrifício, conforme a representação na gravura, era realizada sobre a pedra piramidal localizada diante da "capilla" de Viztzilipuztli. Esse templo religioso é descrito tanto por Acosta como também Solís. No entanto, na gravura, a composição e os ornamentos da capela contribuem para a visualização do horror da prática. 
FreIRE, D. J.

Imitação e

emulação entre o discurso histórico e a arte pictórica na representação da prática

dos sacrifícios no templo de Viztziliputztli

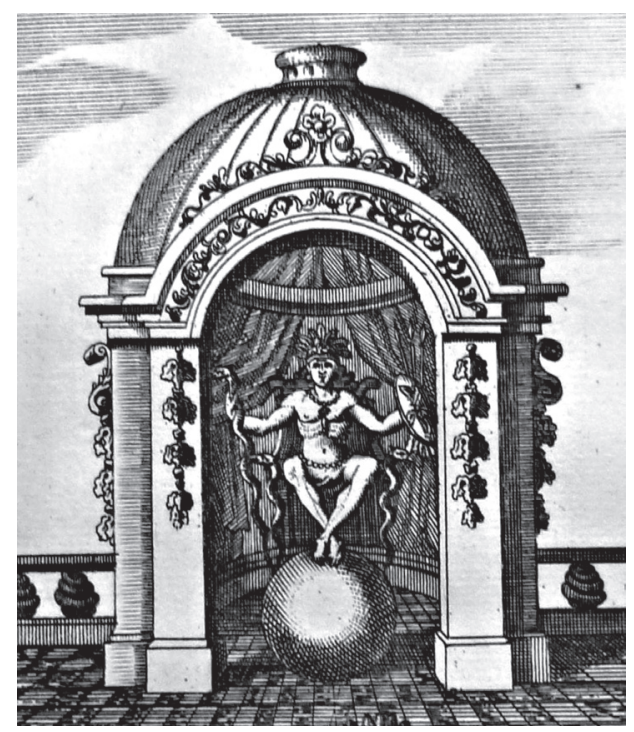

Para representar Viztzilipuztli, o artífice e o gravador compõem a 'capilla' em forma de cúpula bem ao estilo da arquitetura da Península Itálica. De acordo com Migliaccio, em nota aos comentários de Rafael em carta dirigida a Leão X, os romanos revolucionaram as técnicas de construção com a utilização repetida do arco, da abóbada e da cúpula. As arcadas e as abóbadas representam a característica essencial da arquitetura romana, sendo amplamente reproduzidas. Essas características são retomadas, principalmente na Península Itálica, ${ }^{22}$ a partir do final do século XIII e a partir do XIV, como mostra, por exemplo, a gravura realizada por Giuseppe Zocchi, em 1744, da catedral de Florença. O recorte do domo, inserido na sequência, ressalta o modelo que o artífice e o gravador, responsáveis pelas gravuras da Historia de Solís, empenham para a pintura da "capilla" de Viztzilipuztli.
Revista Letras, Curitiba, UFPR, n. 97 , pp. 106-129, jan./jun. 2018. ISSN 2236-0999 (versão eletrônica)

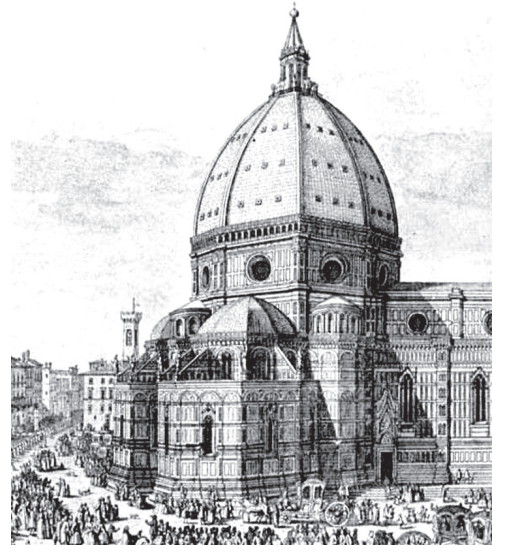

22 De acordo com Luciano Migliaccio (2010, p. 17-18), o papa Leão X, diferentemente de seu antecessor Júlio II, procurou equilibrar "o poderio espanhol favorecendo o rei da França, Francisco I, e ao mesmo tempo estendendo a influência cultural da corte de Roma até os países do norte da Europa, nos quais a sua autoridade começava a ser ameaçada pela influência erasmiana e pela eclosão da Reforma. O papa não avalia ainda em toda a sua força o impacto desse evento, no entanto preocupa-se em enviar a Bruxelas, sede da corte do futuro imperador Carlos $\mathrm{V}$, os desenhos de Rafael para a realização das tapeçarias para a Capela Sistina. Roma se tornará assim um centro que fascina os artistas flamengos, impelindo-os a buscar o contato com a arte antiga e com os novos mestres italianos. Por outro lado, na Espanha, mecenas ligados a Roma começam a encomendar obras destinadas a criar versões locais dos modelos romanos. (...) Em Flandres, como na França e na Espanha, surgem então interpretações do estilo romano, frequentemente inspiradas na exuberante decoração allantica dos manufaturados marmóreos exportados pelos escultores italianos". Grifos nossos. 
A partir da imitação desse modelo de arquitetura, o artífice e o gravador concebem um altar indígena dentro de uma cúpula no alto da meia pirâmide onde eram realizados os sacrifícios. Ainda que o estilo arquitetônico, bem como os adornos, remeta o espectador a um estilo conhecido, a figura do ídolo desfaz de imediato a sensação de familiaridade, pois imita a descrição empenhada pelo cronista, cujo fim é afetar o leitor com o horror de tal visão. Assim descreve Solís a 'capilla' e o ídolo Viztzilipuztli:

[...] Y en la frente una Capilla de mejor fabrica, y materia; cubierta por lo alto con su Techũbre de maderas preciosas : donde tenian el Idolo sobre un Altar muy alto, y detràs de Cortinas. Era de figura humana: y estava sentado en una silla (con apariencias de Trono) fundada sobre un Globo azul, que llamavan Cielo; de cuyos lados salian quatro Varas con cabezas de Sierpes, à que aplicavan los ombros, para conducirle quando le manifestavan al Pueblo. Tenia sobre la cabeza un Penacho de plumas varias; en forma de Paxaro, con el pico, y la cresta de oro bruñido; el rostro de horrible severidad, y mas afeado con dos fajas azules, una sobre la frente, y otra sobre la nariz. En la mano derecha una Culebra ondeada, q le servia de Baston, y en la izquierda quatro Saetas, que veneravan como traidas del Cielo, y una Rodela con cinco plumages blancos, puestos en Cruz, sobre cuyos adornos, y la significacion de aquellas insignias, y colores, dezian notables desvarios, con lastimosa ponderacion.(SOLÍS, 1684, III, XIII, p. 237/238).

A descrição do cronista faz com que o leitor se ponha diante de um ídolo de figura humana, sentado em uma cadeira que se assemelha a um trono, cujo rosto é qualificado por uma aparência de 'horrible severidad'. Em razão de faixas azuis que traz sobre a fronte e o nariz, suas feições se tornam ainda mais enfeadas. Como é um ídolo com suprema autoridade sobre aqueles povos, carrega na mão direita um bastão, que, segundo Solís, tem a forma de cobra. Ao imitar essa imagem, o artífice supera a visão de horror ao retratar Viztzilipuztli desnudo, sentado com as pernas cruzadas em um trono que tem as laterais também em formato sinuoso de cobra. Essas ondulações acrescentam movimento a uma imagem que, na descrição, parece estática ao leitor. Tal recurso pictórico afeta o espectador com sentimentos de aversão e repulsa. Ao buscar a superação da imagem descrita, o artífice e gravador empenham a competição com o texto. A atitude de imitar para emular carrega em si a admiração pelo que se imita, mas também a busca pela superação a partir de uma franca competição entre as artes, sejam elas discursivas ou pictóricas. A imitação, bem como a emulação com os movimentos acrescentados na gravura, pode ser vista com mais exatidão no recorte a seguir. 
FreIRE, D. J.

Imitação e

emulação entre o discurso histórico e a arte pictórica na representação da prática

dos sacrifícios no templo de Viztziliputztli

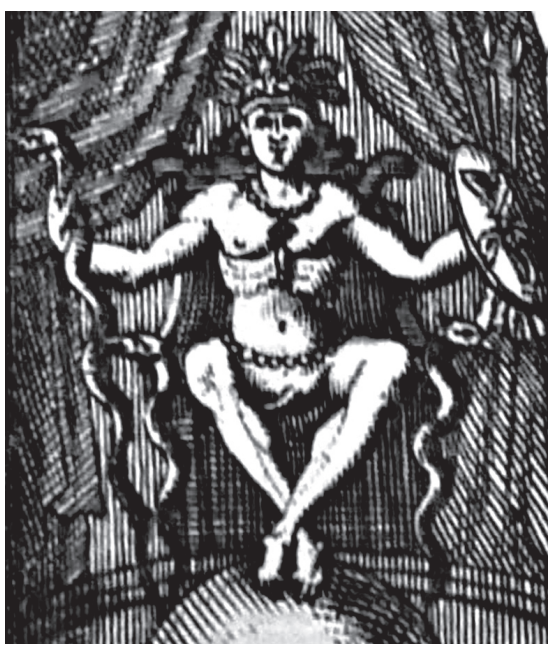

Na gravura, o ídolo ainda é adornado com joias ao redor de seu corpo, provavelmente como forma de ostentar seu poder, um penacho na cabeça e um escudo na mão esquerda com as 'saetas'. Ao fundo, as cortinas nos remetem ao lugar-comum pictórico dos retratos, que indica a nobreza daquele que é retratado. $\mathrm{Na}$ comparação entre imagem e discurso, vemos que o artífice não insere as quatro varas com cabeças de serpentes no globo azul. Como solução, duplica as figurações das cobras nas laterais da cadeira em forma de trono.

Para finalizar a descrição, Solís traz à luz o companheiro de Viztzilipuztli, Tlaloch. ${ }^{23}$ Para o cronista, os indígenas tratavam os dois ídolos como irmãos e amigos entre si, pois dividiam os patrocínios da guerra. Ambos eram iguais no que se refere ao poder e uniformes na vontade. Por esses motivos, quando sacrificavam uma vítima, ofereciam-na tanto a Viztzilipuztli quanto a Tlaloch e davam graças pelos sucessos com equilíbrio na devoção. ${ }^{24}$ No último parágrafo da descrição, Solís retorna à censura da religião e dos rituais indígenas:

El ornato de ambas Capillas, era de inestimable valor, colgadas las paredes, y cubiertos los Altares, de Joyas, y Piedras preciosas, puestas sobre plumas de colores. Y avia de este genero, y opulencia ocho Templos en aquella Ciudad; siendo los menores mas de dos mil, donde se adoravan otros tantos Idolos, diferentes en el nombre, figura, y advocaciõ. Apenas avia calle sin su Dios tutelar; ni se conocia calamidad entre las pensiones de la Naturaleza, que no tuviesse Altar, donde acudir por el remedio.Ellos se fingian, y fabricavan sus Dioses, de su mismo temor; sin conocer, que enflaquecian el poder de los unos, con lo que fiavan de los otros: y el Demonio ensanchava su Dominio por instantes

23 Essa relação está baseada na fonte de Solís, padre José de Acosta, como também na Historia de las Indias do frei dominicano Diego Durán. De acordo com Eduardo Natalino dos Santos (2002, p. 213), "Durán centra sua descrição nos aspectos de Tlaloc presentes em Tenochtitlan, sobretudo no Templo Maior, e classifica-o como companheiro de templo de Huitzilopochtli."

24 O livro Deuses do México Indígena, de Eduardo Natalino dos Santos, trata, com grande alcance, da relevância de Viztzilipuztli (Huitzilopochtli) para os astecas, sendo, assim, de leitura fundamental para compreender tal relevância.
Revista Letras, Curitiba, UFPR, n. 97 , pp. 106-129,

jan./jun. 2018. ISSN 2236-0999 (versão eletrônica) 
: violentissimo Tirano de aquellos Racionales, y en pacifica possession de tantos Siglos.O permissiones inexcrutables del Altissimo! (SOLÍS, 1684, III, XIII, p. 238).

Os deuses indígenas são vistos como calamidades da natureza, cujos templos estavam espalhados pela cidade do México para que todos pudessem acudir sempre que necessário. Para Solís, esses deuses eram fabricados pelo temor dos indígenas e alimentavam a presença do demônio no Novo Mundo. O demônio, por sua vez, se aproveitava dos equívocos de crenças e fé daqueles povos para dilatar seu domínio. Essas permissões eram cedidas pelo próprio Altíssimo e por isso difíceis de compreender, aliás como tudo que envolve os misteriosos desígnios de Deus para os cristãos. Desse modo, Solís finaliza a descrição do templo e de Viztzilipuztli fazendo uso do lugar-comum da presença do demônio no Novo Mundo, pois apenas sua nefasta existência poderia explicar tantos equívocos.

\section{Considerações finais}

A escrita da História no século XVII, na Península Ibérica, tem como base o esquema bíblico cristão, logo, a verdade dos fatos dificilmente pode ser comprovada. No caso das Índias Ocidentais, essa verdade refere-se, comumente, aos deuses indígenas, bem como seus costumes e práticas. A descrição, bem como a narração, é construída a partir da repetição dos lugares-comuns da memória cristã e são estes que a tornam verdadeira para o leitor tanto discreto como vulgar. Nas gravuras, esses lugares-comuns, agora pictóricos, são repetidos, amplificados e intensificados para superar o discurso e comover o leitor e espectador a partir dos afetos com a visão de uma imagem que apenas se formava a partir do juízo da leitura. Nas gravuras em que o templo, o sacrifício e Viztzilipuztli são representados, o artífice e o gravador não poupam o leitor dos detalhes e, assim, imprimem imagens que buscam afetá-lo com o horror das práticas indígenas que, ao final, são justificadas pela presença do demônio. De certa forma, essa presença pode ser vista na gravura pela imagem excessiva e ostensiva do ídolo.

Os procedimentos retóricos de imitar e emular cingem o estabelecimento da competição entre as artes, lembrando que o discurso histórico seiscentista é fabricado pela arte assim como as gravuras. Para o estudo da competição entre a narração histórica e a gravura, consideramos o pressuposto de que a comunicação entre um texto e seu leitor deve estabelecer-se sobre algum tipo de conhecimento das condições que regem sua elaboração. É evidente que não temos a pretensão de conseguir ler a obra da mesma forma que seus contemporâneos, mas sim como leitores do século XXI que levam em consideração reflexões que tanto o autor como os leitores da época fizeram a respeito das histórias sobre a conquista da Nova Espanha e do México, bem como das edições enriquecidas com gravuras. Para essa aproximação entre modos de ler, os textos dos primeiros leitores discretos, que 
FreIRE, D. J.

Imitação $e$ emulação entre o discurso histórico e a arte pictórica na representação

da prática

dos sacrifícios no templo de Viztziliputztli

compõem a parte introdutória da edição princeps, foram de extrema pertinência. Esses discursos legitimam a obra de Dom Antonio de Solís, além de determinar uma forma de leitura regrada.

A partir da competição, estabelecida pelas gravuras que imitam a narração de Solís e Acosta com o objetivo de emulação, é construída e solidificada uma determinada memória da conquista do México. As imagens são determinantes para persuadir o leitor e espectador sobre o desenho que se traça da conquista, legitimando-a a partir da tirania e barbárie dos povos indígenas, principalmente em razão de seus costumes demoníacos, como o sacrifício para glorificar seus deuses. Nesse espaço de competição, entre o discurso histórico e a arte pictórica, ou seja, entre a História e as gravuras, as imagens se sobressaem porque aplicam com esmero os preceitos da perspectiva, da luz e da sombra, do claro e do escuro e do movimento para provocar o ilusionismo que aprofunda o olhar. Com essas regras, o artífice imita o discurso e a própria natureza, afetando o leitor - e espectador - de forma mais vigorosa e eficaz, porque o instrui, comove e agrada. Como sentencia Alberti, o empenho da luz e da sombra, do branco e do preto, além de dar relevo às coisas pintadas, confere prestígio ao pintor, portanto, ao artífice e ao gravador. Assim, todos são beneficiados pelas obras enriquecidas com gravuras, desde o editor até nós, leitores tão distantes dos homens discretos dos séculos XVI e XVII. 


\section{Referências}

ACOSTA, José de. Historia natural y moral de las Indias: en que se tratan de las cosas notables del cielo, elementos, metales, plantas, y animales de ellas, y los ritos, y ceremonias, leyes y gobierno de los indios. Edición preparada por Edmundo O’Gorman. México: Fondo de Cultura Económica, 1962.

ALBERTI, Leon Battista. Da pintura. Apresentação e Prólogo de Leon Kossovitch. Tradução de Antonio da Silveira Mendonça. Campinas/SP: Editora da UNICAMP, 2009.

ARISTÓTELES. Poética. Prefacio de Maria Helena da Rocha Pereira. Tradução e notas de Ana Maria Valente. Lisboa: Fundação Calouste Gulbenkian, 2007.

BENJAMIN, Walter. Magia e técnica, arte e política. Ensaios sobre literatura e história da cultura. Tradução de Sérgio Paulo Rouanet. Prefácio Jeanne Marie Gagnebin. São Paulo: Brasiliense, 1985.

BOSSE, Abraham (Gravador Régio). Tratado da gravura: a água forte, e a buril, e em maneira negra com o modo de construir as prensas modernas, e de imprimir em talho doce. Tradução de José Joaquim Viegas Menezes (Presbytero Mariannense). Lisboa: Tipografia Chalcographica, Typoplastica e Litteraria do Arco do Cego, 1801.

CORTÉS, Hernán. Cartas de relación. Edición de Mario Hernández. Madrid: Historia 16, 1985.

GRANADA, Frei Luis de. Los seis libros de la Rhetórica Eclesiástica o de la manera de predicar. Tradução do latim ao espanhol por ordem do Ilustrísimo Señor O bispo de Barcelona. Madrid: Don Plácido Barco López, 1793.

GRAYSON, Cecil. Introdução. In: ALBERTI, Leon Battista. Da pintura. Apresentação e Prólogo de Leon Kossovitch. Tradução de Antonio da Silveira Mendonça. Campinas/SP: Editora da Unicamp, 1999. p. 33-65.

HANSEN, João Adolfo. Categorias epidíticas da ekphrasis. Revista USP, São Paulo, n. 71, p. 85-105, set./nov., 2006.

MENDIOLA, Alfonso. Retórica, Comunicación y realidad. La construcción retórica de las batallas en las crónicas de la conquista. México: Universidad Iberoamericana, 2003.

MIGLIACCIO, Luciano. Introdução. In: RAFAEL. Cartas sobre arquitetura. Rafael e Baldassar Castiglione: arquitetura, ideologia e poder na Roma de Leão X. Campinas/ São Paulo: Editora UNICAMP/Editora UNIFESP, 2010, p. 17-44.

SANTOS, Eduardo Natalino dos. Deuses do México indígena: estudo comparativo entre narrativas espanholas e nativas. São Paulo: Palas Athena, 2002.

RAFAEL. Cartas sobre arquitetura. Rafael e Baldassar Castiglione: Arquitetura, Ideologia e Poder na Roma de Leão X. Organização de Luciano Migliaccio. São Paulo: Editora UNICAMP/Editora UNIFESP, 2010. 
Freire, D. J.

Imitação e

emulação entre o discurso histórico e a arte pictórica na representação da prática dos sacrifícios no templo de Viztziliputztli

SALINAS, Miguel de. Retórica de la lengua castellana. In: CASAS, Elena. A retórica en España. Madrid: Editora Nacional, 1980. p. 39-200.

SINKEVISQUE, Eduardo. Doutrina seiscentista da arte histórica: discurso e pintura das guerras holandesas (1624-1654). Tese de doutorado. FFLCH/ USP: São Paulo, 2005.

SOLÍS, Don Antonio de. Historia de la conquista de México. Población y progresos de la América Septentrional conocida por el nombre de Nueva España. Madrid: Imprenta de Bernardo de Villa Diego, 1684.

Historia de la conquista de México. Población y progresos de la América Septentrional conocida por el nombre de Nueva España. Nueva Edición, enriquezida con diversas Estampas y aumentada con la Vida del Autor, que escribió Don Juan de Goieneche. Brusselas: Casa de Francisco Foppens, 1704.

TODOROV, Tzvetan. A viagem e seu relato. Revista de Letras, São Paulo, v. 46, n. 1,p. 231-244, jan./ jun. 2006.

Submetido em: 03/12/2017

Aceito em: 29/04/2018 